\title{
ESTIMATION OF COST AND TIME OVERRUN USING NAVFAC P-405
}

\author{
Ms. Nikita Sadashiv Patil \\ Department of Civil Engineering \\ RIT Islampur, Maharashtra, India
}

\author{
Mr. Amol Thorbole \\ Department of Civil Engineering \\ RIT Islampur, Maharashtra, India
}

\begin{abstract}
In construction industry delays and cost overrun are significant problems so it requires investigation at planning stage. This paper gives introduction to the NAVFAC P-405, US Naval handbook for planning and estimation. This is used for site independent duration calculation and also involves steps on using NAVFAC P-405 in calculating delays. Further a method to calculate cost and time overrun for single activity using NAVFAC P-405 is explained in detail with case study.
\end{abstract}

Keywords - Construction planning, time overrun, cost overrun, NAVFAC P-405.

\section{INTRODUCTION}

The construction industry worldwide has good reputation, but it is damaged by highly unpredictable and unreliable time and cost overrun management. Studies on delays can only be useful if only detailed construction process is taken into account that means singular activities rather than the sum of several thousand individual activities.

The Seabee Planner and Estimator's Handbook (NAVFAC P405) was published in 1996. This manual explains how to estimate the quantities of construction work elements and materials, as well as the equipment and labour required. There were also tables for estimating labour that showed the amount of man-hours needed for each function. NAVFAC P-405, the code used by the US Navy, was shown to be suitable for duration fixation in construction operations as part of this study.

In this project we calculate time and cost overrun for five activities using guidelines given by NAVFAC P-405.Time overrun in these five activities is calculated based on standard duration termed as a Quantified Time (QT). The durations are calculated using United States Naval code NAVFAC P-405. This gives uniformity in formulations that takes into account dynamic elements such as weather, site conditions etc.

\section{LITERATURE REVIEW}

The research carried on this topic are shown in form of literature survey are as follows:
1. Ali et al., [2012][1] give good insight into all presently available studies pertaining to activity oriented as well as nonactivity-oriented time waste generation. They conclude lean technique implementation has reduced wastages in construction, reducing time waste in process. Delay analysis, ways to reduce of delay and betterment processes are explained in this paper.

2. Ali et al., [2017] [2] presents the study on activity-oriented time wastes. They propose detailed study and analysis of time waste based on research methodology of inductive reasoning. They provide more realistic approach in quantification of direct time waste (DTW) at single activity level, basing on unit of money.

3. Ali et al., [2018][3] gives the introduction of US navy handbook for planning and estimation, NAVFAC P-405.They explained method to calculate overrun in single activity using NAVFAC P-405 with case study. They suggest that by using this code would bring uniformity and standardize the overrun also they provide proper mitigation measures for overruns.

4. Ali et al.,[4] has explained DCS (data collection system) also delays, and a waste was calculated focusing on single activities. NAVFAC P-405 is used for site independent duration calculation also steps on using NAVFAC P-405 in calculating delays were explored in detail.

5. Bhargava et al., [2010] [5] provides theoretical and empirical evidence that cost, and time overruns need to be considered simultaneously. A model is developed that accounts for simultaneously consideration using three-stage least-square approach. Using this approach, they identified number of factors that affect cost and project time overrun.

6. NAVFAC P-405[1996] [6] provides information on estimating construction work element and material quantities, including equipment and manpower requirement. It also provides tables for estimating labor had been provided to show the number of man-hours required for each function in a construction project. 


\section{International Journal of Engineering Applied Sciences and Technology, 2021 \\ Vol. 6, Issue 5, ISSN No. 2455-2143, Pages 231-234 \\ Published Online September 2021 in IJEAST (http://www.ijeast.com)}

\section{OBJECTIVES OF STUDY}

1. The objectives of proposed research are listed below 1. To calculate cost and time overrun using NAVFAC P-405 for selected activities of building construction project.

2. To compare cost and time overrun values by NAVFAC P-405 and values from site for selected activities.

3. To suggest techniques to reduce time and cost overrun.

4. To implement remedial measures on site.

\section{PROBLEM STATEMENT}

Delays and cost overrun are currently major problem in construction. By using NAVFAC P-405 cost and time overrun will be calculate considering singular activities so we can manage it at activity level.

\section{METHODOLOGY}

Data is collected from site for five activities namely block work, column, slab, Plastering and flooring as they contribute more in schedule i.e. time and cost. Again activity slab in divided into seven sub-activities which are formwork preparation, reinforcement steel fabrication, placing reinforcing steel, mixing concrete, placing concrete, finishing and curing concrete, formwork removal.

Following formulae are used to calculate man-day estimate and quantified time

Man-Day Estimate:

$$
\mathrm{MD}=[(\mathrm{QTY} / \mathrm{UNIT} \text { SIZE }) \times(\mathrm{MHRS} / \mathrm{UNIT}) / 8] \times \mathrm{DF}
$$

MD = Man-Day Estimate QTY = Material quantity from material take off (MTO)

UNIT SIZE = Obtained from labor estimating tables

MHRS/UNIT = Obtained from labor estimating tables

$8=8$ hours per one man-day

$\mathrm{DF}=$ Delay Factor obtained from production efficiency chart

Quantified Time/Duration:

$\mathrm{AF}=$ Availability Factor

$$
\mathrm{QT}=\mathrm{MD} /(\mathrm{CS} \times \mathrm{AF} \times \mathrm{ME})
$$

$\mathrm{ME}=$ Man day Equivalent

$\mathrm{CS}=$ Crew Size

Delay $(\%)=($ Actual time- Quantified time $) /$ Quantified time Cost overrun $(\%)=($ Actual cost - planned cost $) /$ Planned cost

Case study:

Site name: VTP Nest Wing A, Undri Pune

Using NAVFAC P-405 cost and time overrun calculated for block work.

Block size is 6" X 8" X 16"

\begin{tabular}{|l|l|l|}
\hline Qty $\left(\mathrm{m}^{3}\right)$ & Man-Hours & MD \\
\hline 270 & 0.145 & 63.1881 \\
\hline
\end{tabular}

\begin{tabular}{|c|c|c|}
\hline $\begin{array}{c}\text { No. Of } \\
\text { Labours }\end{array}$ & ME & Duration \\
\hline 8 & 1.125 & 8.260 \\
\hline
\end{tabular}

\begin{tabular}{|l|l|}
\hline Production Efficiency & $55-65$ \\
\hline Delay Factor & 1.2 \\
\hline AF & 0.85 \\
\hline MD & 63.188 \\
\hline Working Hrs @ Site & 9 \\
\hline ME & 1.125 \\
\hline No. of Labour & 8 \\
\hline Duration & 8.260 \\
\hline
\end{tabular}

Table -1 Calculation of percentage delays for blockwork

\begin{tabular}{|c|c|c|c|c|c|c|}
\hline \multirow{2}{*}{ Set No. } & \multicolumn{2}{|c|}{$\begin{array}{c}\text { Volume of Work } \\
\left(\mathrm{m}^{3}\right)\end{array}$} & \multicolumn{4}{|c|}{$\begin{array}{c}\text { Duration } \\
\text { (days) }\end{array}$} \\
\cline { 2 - 7 } & Estimate & Actual & QT & Plan & Act & $\%$ Delay \\
\hline 1 & 90 & 90 & 8.26 & 9 & 11.5 & 39.22716 \\
\hline 2 & 90 & 90 & 8.26 & 9 & 11 & 33.17381 \\
\hline 3 & 90 & 90 & 8.26 & 9 & 10.9 & 31.96314 \\
\hline
\end{tabular}

Average time overrun: $34.8 \%$

Average cost overrun: $7.7 \%$

Table -2 Calculation of percentage delays and cost overrun for other activities

\begin{tabular}{|c|l|c|c|}
\hline Sr.No. & \multicolumn{1}{|c|}{ Activity } & $\begin{array}{c}\text { Average Time } \\
\text { overrun (\%) }\end{array}$ & $\begin{array}{c}\text { Average cost } \\
\text { overrun (\%) }\end{array}$ \\
\hline 1 & Column & 7.8 & 13.8 \\
\hline 2 & Slab formwork & 13.2 & 46 \\
\hline 3 & $\begin{array}{l}\text { Reinforcing steel } \\
\text { fabrication }\end{array}$ & 21.8 & 18 \\
\hline 4 & $\begin{array}{l}\text { Placing reinforcing } \\
\text { steel }\end{array}$ & 9.4 & 13.8 \\
\hline 5 & Mixing concrete & 11.4 & 12 \\
\hline 6 & Placing concrete & 16 & 19.7 \\
\hline 7 & Finishing & 29.2 & 14.3 \\
\hline 8 & Curing & 9.5 & 22 \\
\hline 9 & Flooring & 12.6 & 6.4 \\
\hline 10 & Plastering & 4.6 & 7.3 \\
\hline
\end{tabular}




\section{International Journal of Engineering Applied Sciences and Technology, 2021 \\ Vol. 6, Issue 5, ISSN No. 2455-2143, Pages 231-234 \\ Published Online September 2021 in IJEAST (http://www.ijeast.com)}

At site average percentage delays are $34.8 \%, 13.2 \%, 21.8 \%, 11.4 \%, 16 \%, 29.2 \%, 12.6 \%$ for activities blockwork,slab formwork, reinforcing steel fabrication, mixing concrete, placing concrete, finishing and flooring respectively. Following are the reasons and remedial measures for site one:

Reasons:
1. Shortage of material on site
2. Shortage of skilled labours.
3. Frequent failure or breakdown of equipment's

Remedial measures:

1) Make separate material procurement department. So the delivery of construction material should not be delayed on site to work in a planned order. Early planning of material should be done from lacking of materials and also dead stock will not exhaust from the stores

2) Owners and contractors should manage his financial resources not to face money problems during construction stage and plan a cash flow by utilizing progress payments to every staff and labours on site. Pay progress payments on time because it increases the interest of working to contractor and staff

3) Appoint skilled workers. Unskilled or uneducated workers may lead to inefficient work and cause accidents during construction and that may have impact on quality of work.

4) The workers or staff will be more effective if there are enough members of engineers, planning managers, technicians, and foremen, so the responsibilities would be shared between all of them.

5) The updating of technology utilization and new construction equipment's should be used.

\section{Implementation:}

We calculated the delays for floor three of site one for five activities. By considering results of overrun and reasons and remedial measures we again collect data for $7^{\text {th }}$ floor for same activities. Calculations are made and again delays are calculated to check weather delays are reduced or not.

\begin{tabular}{|c|c|c|}
\hline Qty $\left(\mathrm{m}^{3}\right)$ & Man-Hours & MD \\
\hline 270 & 0.145 & 63.1881 \\
\hline
\end{tabular}

\begin{tabular}{|c|c|c|}
\hline $\begin{array}{c}\text { No. Of } \\
\text { Labours }\end{array}$ & ME & Duration \\
\hline 8 & 1.125 & 8.260 \\
\hline
\end{tabular}

Table -3 Calculation of percentage delays for blockwork after implementation

\begin{tabular}{|c|c|c|c|c|c|c|}
\hline \multirow{2}{*}{ Set No. } & \multicolumn{2}{|c|}{$\begin{array}{c}\text { Volume of Work } \\
\left(\mathrm{m}^{3}\right)\end{array}$} & \multicolumn{4}{|c|}{$\begin{array}{c}\text { Duration } \\
(\text { days })\end{array}$} \\
\cline { 2 - 7 } & Estimate & Actual & QT & Plan & Act & $\%$ Delay \\
\hline 1 & 90 & 90 & 8.26 & 9 & 9 & 8.9603 \\
\hline 2 & 90 & 90 & 8.26 & 9 & 9 & 8.9603 \\
\hline 3 & 90 & 90 & 8.26 & 9 & 9 & 8.9603 \\
\hline
\end{tabular}

Table -4 Calculation of percentage delays for other activities after implementation

\begin{tabular}{|c|l|c|}
\hline Sr.No. & \multicolumn{1}{|c|}{ Activity } & $\begin{array}{c}\text { Average Time } \\
\text { overrun (\%) }\end{array}$ \\
\hline 1 & Column & 1.87 \\
\hline 2 & Slab formwork & 6.34 \\
\hline 3 & $\begin{array}{l}\text { Reinforcing steel } \\
\text { fabrication }\end{array}$ & 11.08 \\
\hline 4 & $\begin{array}{l}\text { Placing reinforcing } \\
\text { steel }\end{array}$ & 1.83 \\
\hline 5 & Mixing concrete & 4.23 \\
\hline 6 & Placing concrete & 3.68 \\
\hline 7 & Finishing & 11.08 \\
\hline 8 & Curing & 3.68 \\
\hline 9 & Flooring & 2.78 \\
\hline 10 & Plastering & 2.22 \\
\hline
\end{tabular}

\section{CONCLUSION}

From objective one it can be concluded that quantified time is calculated for selected activities for four sites. Activities are selected on the basis of their impact of that activity on cost and time. Quantified time is calculated by considering delay factor, availability factor, crew size, man-hours unit, man day estimate, man day equivalent by using NAVFAC P-405.

From objective two it is concluded that comparison is made between quantified time calculated by using NAVFAC P-405 and values of cost and time taken from site estimate. From this comparison time and cost overrun values are obtained.

From objective three it is concluded that from all the percentage delays the values equal to or greater than $10 \%$ are considered as an overrun and all other delay values are neglected. By questionnaire survey we find reasons for delays and then we suggest some remedial measures for those activities.

From objective four it is concluded that we implement quantified time calculated using NAVFAC P-405 and remedial measures on site one and then calculate percentage delays again. 


\section{International Journal of Engineering Applied Sciences and Technology, 2021 Vol. 6, Issue 5, ISSN No. 2455-2143, Pages 231-234 \\ Published Online September 2021 in IJEAST (http://www.ijeast.com)}

Table -5 Comparison between results before and after implementation

\begin{tabular}{|c|l|c|c|c|}
\hline Sr.No. & Activity & $\begin{array}{c}\text { Delay without } \\
\text { using } \\
\text { NAVFAC } \\
\text { P-405 (\%) }\end{array}$ & $\begin{array}{c}\text { Delay when } \\
\text { using } \\
\text { NAVFAC } \\
\text { P-405 (\%) }\end{array}$ & $\begin{array}{c}\text { Percentage } \\
\text { delay } \\
\text { reduced } \\
(\%)\end{array}$ \\
\hline 1 & Blockwork & 34.8 & 8.9 & 25.9 \\
\hline 2 & Slab formwork & 13.2 & 6.3 & 6.9 \\
\hline 3 & $\begin{array}{l}\text { Reinforcing } \\
\text { steel } \\
\text { fabrication }\end{array}$ & 21.8 & 11 & 10.8 \\
\hline 4 & $\begin{array}{l}\text { Mixing } \\
\text { concrete }\end{array}$ & 11.4 & 4.23 & 7.17 \\
\hline 5 & $\begin{array}{l}\text { Placing } \\
\text { concrete }\end{array}$ & 16 & 3.68 & 12.32 \\
\hline 6 & Finishing & 29.2 & 11 & 18.2 \\
\hline 7 & Flooring & 12.6 & 2.78 & 9.82 \\
\hline
\end{tabular}

As per above table percentage delays reduced are $25 . \%, 6.9 \%, 10.8 \%, 7.17 \%, 12.32 \%, 18.2 \%, 9.82 \%$ for activities blockwork,slab formwork, reinforcing steel fabrication, mixing concrete, placing concrete, finishing and flooring respectively. Also we can say that average percentage delays reduced after using NAVFAC P-405 is 13\%. From results obtained percentage delays are reduced by using NAVFAC P405. So we can use NAVFAC P-405 for planning of residential buildings

\section{REFERENCES}

[1] Ali, S., Ali, A. and Arun, C.(2012). "Time Waste and Delays in Construction Projects: A State of Art Report", NICMAR-Journal of Construction Management.63-73.

[2] Ali, S., Ali, A., Arun C. and Krishnamurthy, K. (2017). "New Approach For Direct And Indirect Time Wastes In Civil Construction Engineering", International Journal of Civil Engineering And Technology(IJCIET).817-832.

[3] Ali, S. ,Ali, A., Arun C and Krishnamurthy, K.(2018). "A Case Study On Implementing NAVFAC P-405 At Indian Construction Sites For Estimating Time And Cost Overrun", NICMAR-Journal Of Construction Management.

[4] Ali, S., Ali, A., Krishnamurthy, K., Arun, C., James, S., Mathew, N., Sujatha, A. and Sumayya, P. "Waste Data Processing Algorithm In Singular Construction Activities: A Case Involving Implementation Of NAVFAC P-405", Journal Of Architectural Engineering Technology.
[5] Bhargava, A., Labi, S., Sinha, K., and Mannering, F. (2010). "Three-Stage Least-Squares Analysis Of Time And Cost Overruns In Construction Contracts" Journal Of Construction Engineering And Management. 12071218 .

[6] Naval Construction Force, USA (1996).NAVFAC P-405, Seabee Planner's and Estimator's Handbook. 